\title{
Holocene environments of the sclerophyll woodlands of the Wet Tropics of northeastern Australia
}

\section{Patrick T. Moss}

Climate Research Group, School of Geography, Planning and Environmental Management, The University of Queensland, St Lucia, Queensland

patrick.moss@uq.edu.au

\section{Richard Cosgrove}

La Trobe University, Bundoora, Victoria

\section{Åsa Ferrier}

La Trobe University, Bundoora, Victoria

\section{Simon G. Haberle}

The Australian National University, Canberra, ACT

\section{Introduction}

The Wet Tropics region of northeastern Australia has been the focus of palynological research into the late Quaternary history of climate, vegetation and human environmental impact for a number of years (Moss and Kershaw 2000, 2007; Kershaw et al. 2007, 2003a, 2003b; Kershaw 1994, 1986). Numerous palynological records covering the Holocene period have been examined, but they have either been concentrated within the core rainforest area due to the availability of volcanic crater sites on the Atherton Tableland (e.g. Kershaw 1983, 1975, 1971, 1970; Walker and Chen 1987; Chen 1988; Walker 2007); and/or situated in coastal areas where successional processes in mangroves have tended to mask more regional signals (e.g. Grindrod and Rhodes 1984; Grindrod 1985; Crowley et al. 1990; Gagan et al. 1994; Crowley and Gagan 1995). Recently, there has been a focus on high-resolution records that investigate 


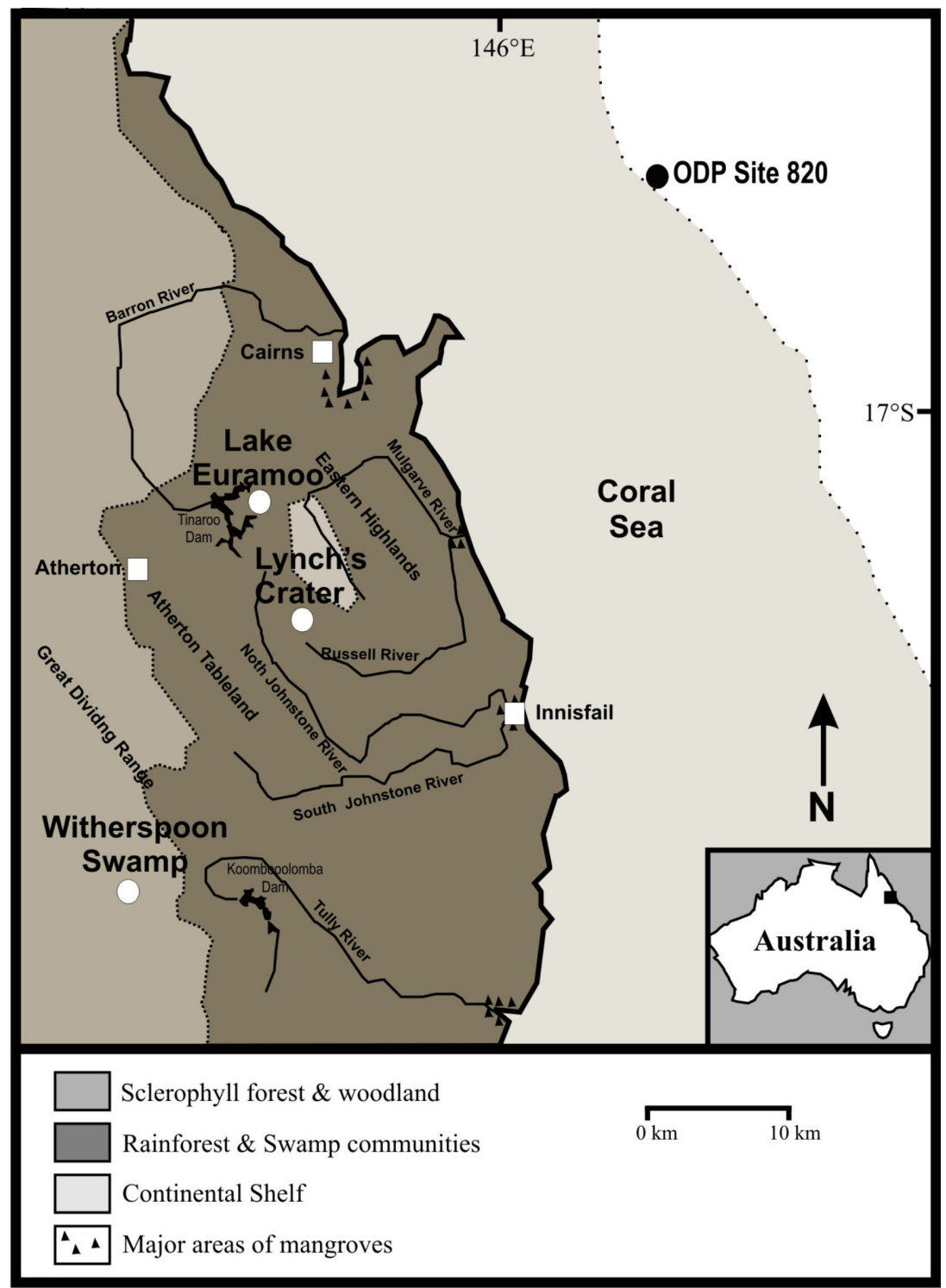

Figure 1. Location of the Witherspoon Swamp site in relation to major environmental features of the Wet Tropics region, as well as the Lynch's Crater, Lake Euramoo sites and ODP 820 sites.

the response of the Wet Tropics ecosystem to rapid climate change and human impact for the Late Quaternary period. A key record, located within the modern mesophyll rainforests of the Atherton Tableland region, was taken from Lake Euramoo (Haberle 2005; Figure 1). This $8.4 \mathrm{~m}$ core covers the past 23,000 years and provides a high-resolution record (i.e. centennial to decadal scale) of vegetation change and fire history for the region. Five pollen zones were identified, with dry sclerophyll woodland dominating from 23,000 to 16,800 cal BP; changing to wet sclerophyll forest with patches of mesophyll rainforest from 16,800 to $8600 \mathrm{cal} \mathrm{BP}$; followed by expansion of mesophyll rainforest from 8600 to $5000 \mathrm{cal} \mathrm{BP}$; slight contraction in mesophyll rainforest from 5000 to $70 \mathrm{cal} \mathrm{BP}$; and degraded mesophyll rainforest with an increase in fire and invasive species from $70 \mathrm{cal} \mathrm{BP}$ to the present. The process of rainforest expansion was thought to be at least partly controlled by changes in insolation (dominated by the precessional component at equatorial latitudes), although local factors (i.e. biomass change associated with forest development) and human impact, particularly fire use, have been suggested to also have played significant roles (Haberle 2005).

Archaeological research within the Wet Tropics suggests that people have occupied the region for at least the past 40,000 to 30,000 years (Kershaw 1986; Cosgrove et al.2007). However, it appears that human occupation occurred at a very low intensity until around $2500 \mathrm{cal} \mathrm{BP}$, peaking after $1500 \mathrm{cal} \mathrm{BP}$, when the exploitation of toxic nut varieties and the development 
of permanent occupation in the rainforests of this region occurred (Haberle and David 2004; Cosgrove et al. 2007). It has been suggested that fire, El Niño Southern Oscillation (ENSO) activity and shifting vegetation played a significant role in the history of permanent human occupation within the region (Haberle and David 2004; Cosgrove et al. 2007). This implies significant linkages between environmental alterations from the region and human cultural responses.

A broader picture of environmental change for the Wet Tropics region is provided through palynological analysis of sediment cores taken from Witherspoon Swamp. These records are some of the first to examine a significant portion of the Holocene period (i.e. past 8000 years) from the scelerophyll communities located to the west of the Wet Tropics region, and as such, provide a complementary site to the existing records taken from the rainforest communities of the region. In particular, the Witherspoon Swamp records provide an assessment of changes in the rainforest-sclerophyll boundary, as well as possible insight into human impacts on the sclerophyll communities of the Wet Tropics region.

\section{Regional setting and methods}

A key characteristic of the Wet Tropics region is the substantial topographic variation that has a significant influence on the area's climate and vegetation (Tracey 1982; Figure 1). Marked climatic gradients are associated with the variable physiography, with mean annual temperatures exceeding $24^{\circ} \mathrm{C}$ along the coast, falling below $21^{\circ} \mathrm{C}$ on the Atherton Tableland, and to below $17^{\circ} \mathrm{C}$ on the highest peaks. The southeasterly trades dominate the region's weather patterns and produce much of the rain, although this is supplemented by monsoonal northwesterlies and occasional cyclones. Most precipitation falls in summer (November to April) but almost continuous cloud cover maintains moist conditions throughout the year on the higher ranges. The region is also highly sensitive to ENSO variability, with significant reductions in rainfall during El Niño years when the activity of the trade winds is much reduced, and significant increases in precipitation during La Niña years when there are stronger southeasterlies, which is also augmented by the more southerly movement of the Inter Tropical Convergence Zone, as well as increased cyclone activity (Nichols 1992). Vegetation distribution is closely linked to the climatic and topographic variability. Rainforest, including floristically similar swamp communities on the poorly drained coastal lowlands, occupy the high rainfall $[>1500 \mathrm{~mm}$ Mean Annual Precipitation (MAP)] parts of the region, which extend from the coast to the western edge of the Atherton Tableland. Sclerophyll communities, most frequently dominated by eucalypts, generally replace rainforest in areas that receive fewer than $1500 \mathrm{~mm}$ of MAP, which include the western areas of the study region, as well as a large patch in the rain shadow to the west of the Eastern Highlands (see Figure 1). Mangrove communities are found in lowenergy coastal embayments, such as Trinity Inlet near Cairns, Mutchero Inlet at the mouth of the Russell and Mulgrave Rivers, at the mouth of the North and South Johnstone Rivers and at the mouth of the Tully River.

Witherspoon Swamp (17 $49^{\prime} \mathrm{S}, 145^{\circ} 24^{\prime} \mathrm{E}$, elevation $\left.652 \mathrm{~m}\right)$ is located in the southwestern corner of the Atherton Tableland (commonly referred to as the Evelyn Tableland) within the sclerophyll woodland communities of the Wet Tropics region, and is around $5 \mathrm{~km}$ to $10 \mathrm{~km}$ from the nearest rainforest communities (Figure 1). The swamp itself is situated within a small depression and consists of an area of relatively permanent water with numerous reeds, sedges and other aquatic plants growing on the swamp surface (Figure 2). It is surrounded by a large area of Melaleuca forest to the north and east, and the regional vegetation is characterised by open eucalypt forest with a grassy understorey.

Precipitation is around $800 \mathrm{~mm}$ to $1000 \mathrm{~mm}$ per year and the dominant land-use at present 


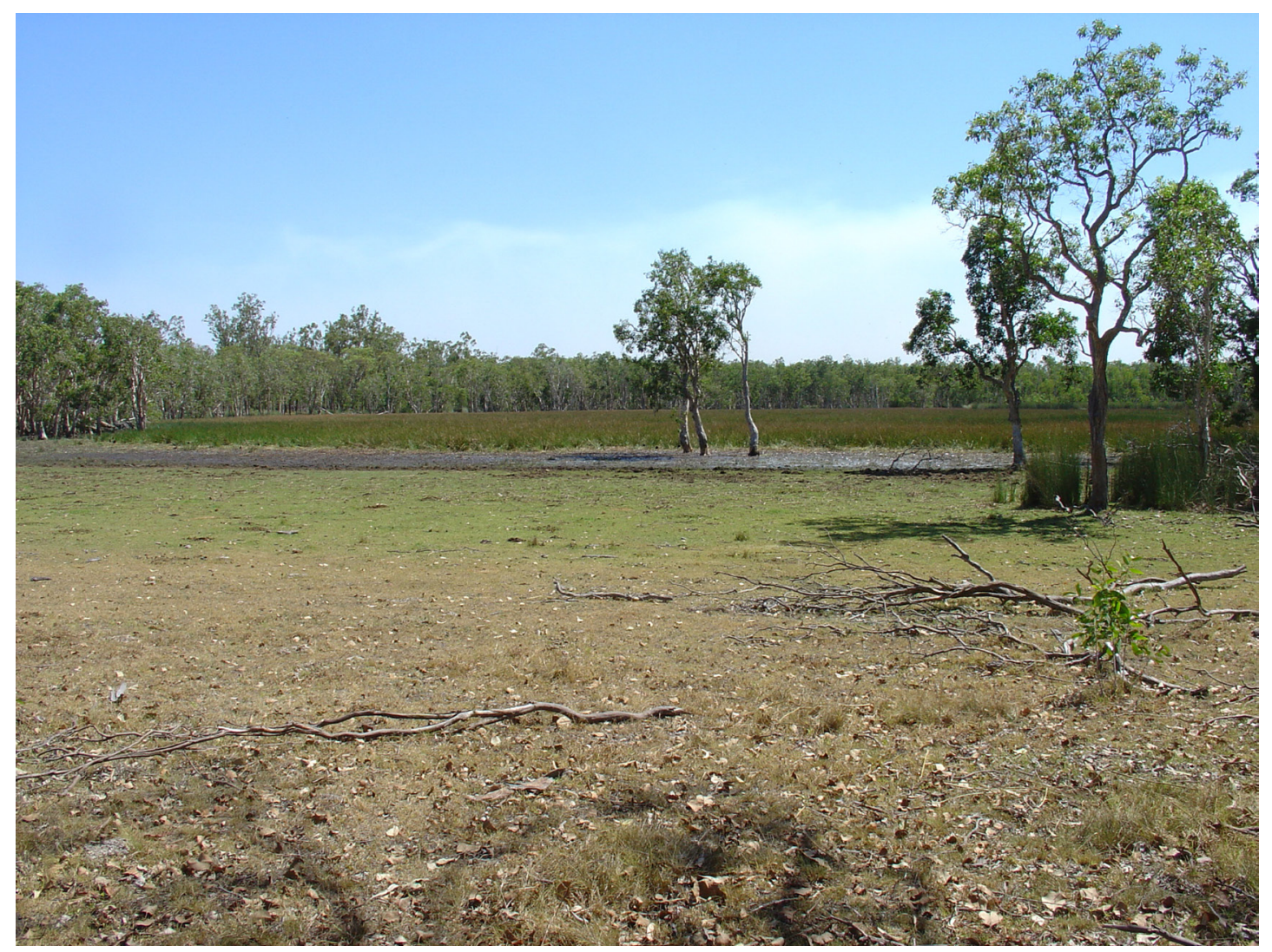

Figure 2. Photograph of the Witherspoon Swamp site.

is cattle grazing. The cores obtained from this site are the first ones to be taken from a modern sclerophyll community from the region. Two cores were obtained from the site, the first (WS 1) was collected in October 2004 from the edge of the swamp and is $1.4 \mathrm{~m}$ in length, while the second (WS 2) was collected in November 2006 from the centre of the swamp and is 1.9 $\mathrm{m}$ long.

The Witherspoon Swamp samples were prepared for pollen analysis using the technique developed by van der Kaars (1991). This involved using sodium pyrophosphate to disaggregate the sediments, which were then further processed by using sodium polytungstate (specific gravity of 2.0) to float the lighter organic fraction from the heavier minerogenic component. The samples then underwent acetolysis to darken the pollen grains, remove extraneous organic matter and improve their visibility under a light microscope. All samples were mounted in glycerol. Pollen identification and counting was undertaken using a light microscope at $\mathrm{x} 400$ magnification and the pollen sum consisted of a minimum of 300 dryland pollen taxa. Charcoal analysis involved counting all black angular particles above $5 \mathrm{~mm}$ in diameter as carbonised particles across three transects, and exotic Lycopodium spores were also counted to allow for the calculation of charcoal concentrations or carbonised particles per cubic $\mathrm{cm}$ (Wang et al. 1999).

Pollen diagrams were produced using TGView (Grimm 2004) and the pollen diagrams for WS 1 and WS 2 include both pollen and charcoal counts (see Figures 3 and 4). The pollen diagrams are divided into zones based on the results of a stratigraphically constrained classification undertaken by CONISS (Grimm 1987,2004) on taxa contained within the pollen sum. Age control was based on AMS radiocarbon dating of bulk sediments from both cores, with two radiocarbon dates from WS 1 (determined by the University of Waikato radiocarbon laboratory) and two radiocarbon dates from WS 2 (undertaken by the Australian Nuclear Science and Technology Organisation). The Hughen et al. (2006) chronology was used to 
provide calibrated ages for both records and all dates are presented in Table 1. In addition, sediment samples for Witherspoon WS 2 underwent Loss-on-Ignition analysis, which involved heating the samples at $490^{\circ} \mathrm{C}$ for 12 hours to remove the organic fraction from the samples. Figure 4 presents the results of the analyses (as percentage ash content or inorganic fraction per dry weight).

Table 1. Radiocarbon dates for the WS 1 and WS 2 cores.

\begin{tabular}{|c|c|c|c|c|}
\hline Record & Top (m) & Bottom (m) & Age BP (14C years) & Cal BP (median) \\
\hline WS 1 & 0.48 & 0.50 & $1709 \pm 122$ & 1974 \\
\hline WS 1 & 1.38 & 1.40 & $4259 \pm 35$ & 4919 \\
\hline WS 2 & 0.60 & 0.65 & $1980 \pm 40$ & 2287 \\
\hline WS 2 & 1.85 & 1.95 & $6830 \pm 60$ & 7889 \\
\hline
\end{tabular}

\section{The Witherspoon Swamp pollen records}

Both of the cores (WS 1 and WS 2) taken from Witherspoon Swamp are dominated by sclerophyll taxa and relatively low rainforest gymnosperm and angiosperm values are recorded (Figures 3 and 4). In addition, both cores provide a record of vegetation change that extends back to the early to mid-Holocene period. The base $(140 \mathrm{~cm})$ of WS 1 dates to ca. $5000 \mathrm{cal} \mathrm{BP}$, with an age of ca. $2000 \mathrm{cal} \mathrm{BP}$ at $45 \mathrm{~cm}$, while the base $(190 \mathrm{~cm})$ of the longer WS 2 core dates to ca. $7800 \mathrm{cal} \mathrm{BP}$, with an age of $2300 \mathrm{cal} \mathrm{BP}$ at $60 \mathrm{~cm}$. The key difference between the cores is in terms of representation of wetland taxa, with higher aquatic values, particularly Cyperaceae in WS 2, while WS 1 shows higher Selaginella values from $140 \mathrm{~cm}$ to $100 \mathrm{~cm}$. This difference between the two pollen records may reflect the location of the cores within the swamp. WS 1 is located closer to the swamp edge and the higher representation of Selaginella may therefore reflect this taxa growing on the relatively exposed swamp edge. In contrast, WS 2 was taken in the centre of the lake and the higher aquatic values represent sedges and other aquatic taxa (e.g. Polygonum and Nymphoides) that are growing within the swamp itself.

The classification of the pollen undertaken on the cores identified six zones in both records. The zones are categorised by the depth values as it was thought that two radiocarbon ages per record were insufficient for the development of a reliable age model. The six zones in both records are described in more detail below:

\section{Core WS 1}

\section{Zone WS $1 \mathrm{~A}(140 \mathrm{~cm}$ to $130 \mathrm{~cm})$}

This zone is characterised by the highest representation of rainforest gymnosperm and angiosperm values in the core (particularly at $140 \mathrm{~cm}$ ). Poaceae dominate the dryland taxa and Casuarinaceae is the most significant sclerophyll arboreal taxon. Selaginella occurs in low abundances, while Cyperaceae, Polygonum and Nymphoides are the dominant aquatic taxa. Charcoal values maintain a low representation in this zone.

\section{Zone WS $1 B(120 \mathrm{~cm}$ to $100 \mathrm{~cm})$}

A significant increase in Poaceae is observed in this zone, while sclerophyll arboreal taxa, rainforest gymnosperms and rainforest angiosperms decrease. Aquatic taxa and pteridophytes, particularly the fern ally Selaginella, reach their highest abundances in this zone. The highest charcoal values in the record are observed in this zone at $100 \mathrm{~cm}$. 


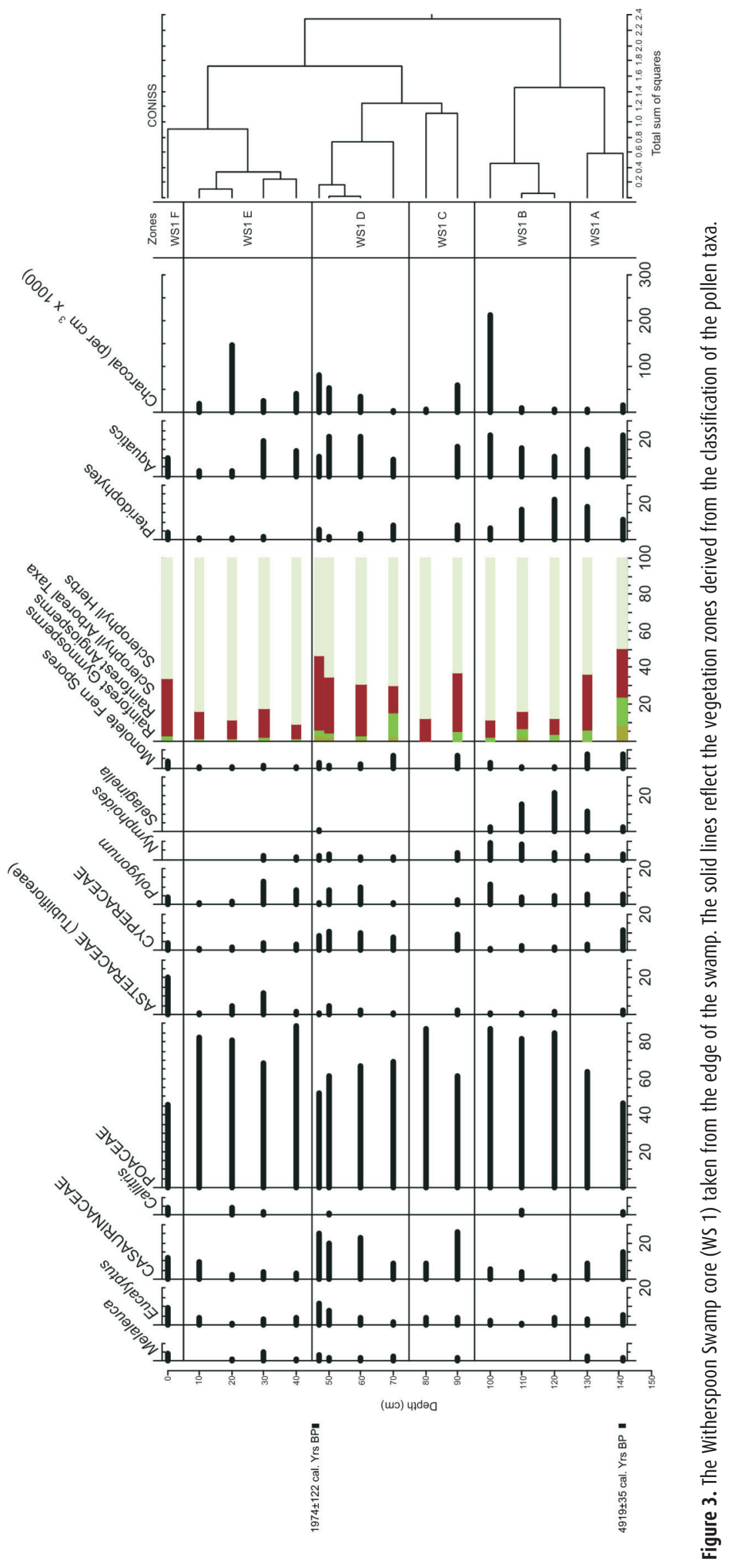




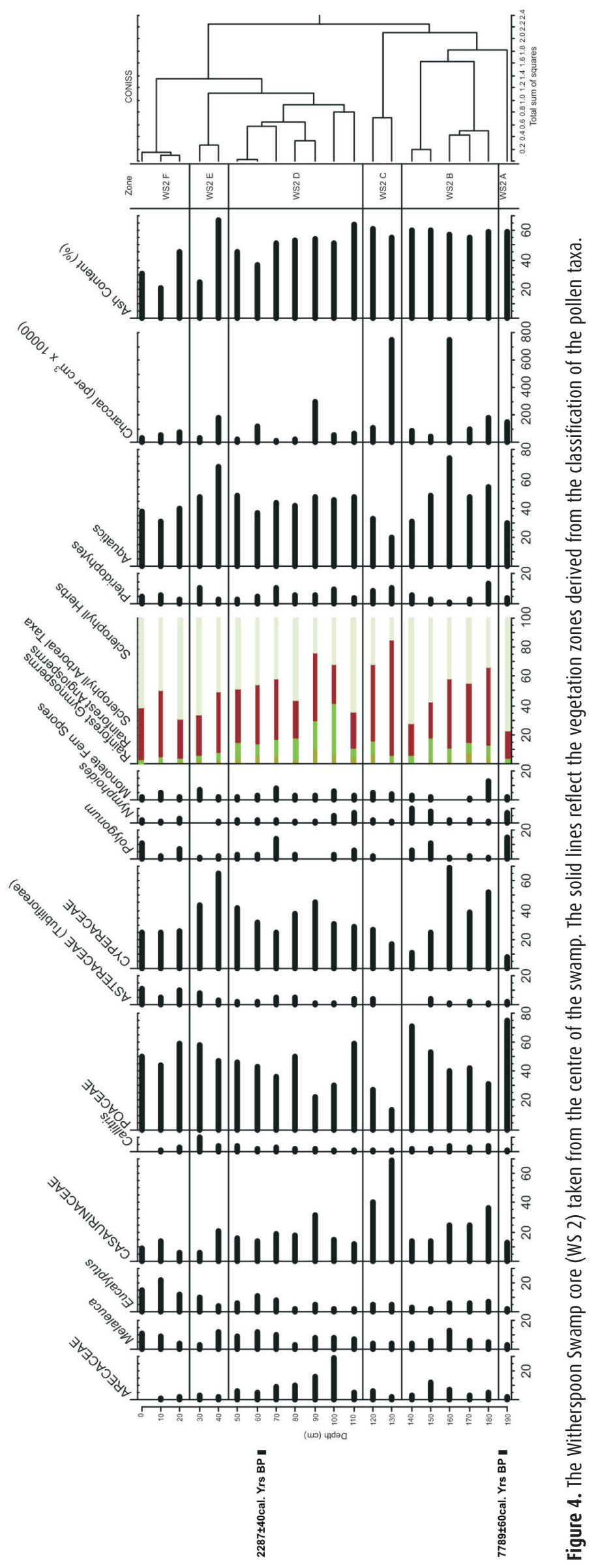




\section{Zone WS $1 C(90 \mathrm{~cm}$ to $80 \mathrm{~cm})$}

This zone is characterised by an increased representation of sclerophyll arboreal taxa, particularly Casuarinaceae. Poaceae values initially decrease at $90 \mathrm{~cm}$ but increase again at $80 \mathrm{~cm}$, mainly at the expense of rainforest gymnosperms and rainforest angiosperms, which completely disappeared from the record at this depth. Aquatic and pteridophyte values, particularly Selaginella (which do not return in any significant values in the rest of the record) sharply decrease and are also absent from the $80 \mathrm{~cm}$ depth. Charcoal values decrease sharply in this zone.

\section{Zone WS $1 \mathrm{D}(70 \mathrm{~cm}$ to $45 \mathrm{~cm})$}

A decrease in Poaceae values is seen in this zone, while there is an increase in sclerophyll arboreal taxa, particularly Casuarinaceae, Eucalyptus and Melaleuca. In fact, the Myrtaceous taxa reach their highest values in the record at $45 \mathrm{~cm}$. Rainforest gymnosperm and rainforest angiosperm values increase, as do aquatic and pteridophyte values. Charcoal values increase towards the top of this zone.

\section{Zone WS $1 E(40 \mathrm{~cm}$ to $10 \mathrm{~cm})$}

This zone is characterised by an increased representation of Poaceae, while sclerophyll arboreal taxa, rainforest gymnosperm and rainforest angiosperm values decrease sharply. Pteridophyte abundances decline, while aquatic values, particularly Polygonum, initially increase from $40 \mathrm{~cm}$ to $30 \mathrm{~cm}$ and then sharply decline. Charcoal values are consistent with the previous zone, but there is a peak (the second highest in the record) at $20 \mathrm{~cm}$.

\section{Zone WS $1 F(0 \mathrm{~cm})$}

Sclerophyll arboreal taxa abundances increase sharply in this zone. Poaceae values decline and there is a sharp increase in representation of Asteraceae (Tubilifloreae) pollen. In addition, there is an increased representation of rainforest angiosperm, ferns and aquatics in this zone, but very low charcoal values are observed.

\section{Core WS 2}

\section{Zone WS $2 A(190 \mathrm{~cm})$}

Poaceae dominates in this zone, with low representation of rainforest taxa and sclerophyll arboreal taxa. Relatively low aquatic values are seen in this zone, with Polygonum being the dominant taxa. Charcoal values are low and ash content is ca. $60 \%$ and maintains this value until the top of zone WS 2D $(60 \mathrm{~cm})$.

\section{Zone WS $2 B(180 \mathrm{~cm}$ to $140 \mathrm{~cm})$}

This zone is characterised by a significant increase in rainforest gymnosperm, rainforest angiosperm (particularly Arecaceae) and sclerophyll arboreal taxa, particularly Casuarinaceae. Poaceae values initially decline but then increase towards the top of the zone. Aquatic values increase, with Cyperaceae dominating from $180 \mathrm{~cm}$ to $160 \mathrm{~cm}$, then decrease from $150 \mathrm{~cm}$ to $140 \mathrm{~cm}$, being replaced by Polygonum and Nymphoides. There is a peak in monolete fern spores at $180 \mathrm{~cm}$, as well as a peak in charcoal at $160 \mathrm{~cm}$.

\section{Zone WS $2 C(130 \mathrm{~cm}$ to $120 \mathrm{~cm})$}

Poaceae values sharply decline in this zone and there is a significant increase in Casurainaceae representation. There is a peak in rainforest gymnosperm and angiosperm values at $120 \mathrm{~cm}$. Aquatic values decline in this zone and there is a peak in charcoal at $130 \mathrm{~cm}$. 


\section{Zone WS 2D $(110 \mathrm{~cm}$ to $50 \mathrm{~cm})$}

This zone observes a significant increase in Poaceae representation, a sharp decline in Casuarinaceae values and a peak in Arecaceae values, particularly at $100 \mathrm{~cm}$. There is also increased representation of Melaleuca and Eucalyptus at $70 \mathrm{~cm}$ to $50 \mathrm{~cm}$. Aquatic values, particularly Cyperaceae, increase in this zone and there is a peak in Polygonum and monolete fern spores at $70 \mathrm{~cm}$. Charcoal maintains relatively low representation in this zone, except for a peak at $90 \mathrm{~cm}$. Ash content values are around 50\% to $60 \%$ from $110 \mathrm{~cm}$ to $70 \mathrm{~cm}$ and then decline to $40 \%$ at $60 \mathrm{~cm}$, suggesting an increase in organic content at this depth.

\section{Zone WS $2 E(40$ to $30 \mathrm{~cm})$}

Poaceae abundances increase in this zone and there is a decrease in Casuarinaceae and Arecaceae values. Melaleuca has a peak at $40 \mathrm{~cm}$ and there is a peak in Eucalyptus at $30 \mathrm{~cm}$. Callitris and Cyperaceae observe their highest values in the record in this zone and there is a peak in monolete fern spores at $30 \mathrm{~cm}$. Charcoal values are relatively low in this zone as well as the next one (WS 2F). There is an initial peak at $40 \mathrm{~cm}$ in ash content (ca.70\%), which sharply declines to ca. $20 \%$ at $30 \mathrm{~cm}$.

\section{Zone WS $2 F(20 \mathrm{~cm}$ to $0 \mathrm{~cm})$}

This zone is characterised by continued high values of Poaceae, as well as an increase in the sclerophyll arboreal taxa. There is also a sharp increase in Asteraceae (Tublifloreae) abundances and the disappearance of Callitris in the top sample. Cyperaceae values decrease and there is a peak in Polygonum values at $20 \mathrm{~cm}$ and $0 \mathrm{~cm}$. Ash content is lowest in this zone ranging from $50 \%$ to $20 \%$.

\section{Holocene rainforest-sclerophyll boundary stability}

One of the key features of the Witherspoon Swamp records is the relative stability in the rainforest-sclerophyll boundary in the Wet Tropics region during the Holocene period. In general, both the WS 1 and WS 2 cores are dominated by sclerophyll trees, particularly Casuarinaceae, and grasses. Peaks in rainforest gymnosperms and angiosperms may reflect minor expansions in the rainforest boundary (which is within $5 \mathrm{~km}$ to $10 \mathrm{~km}$ of the site). Significant rainforest taxa in both records (e.g. palms) can be typical of swamp communities rather than a reflection of the presence of extensive mesophyll rainforest (i.e. as would be high values of Cunoniaceae and Elaeocarpus). In addition, Witherspoon Swamp is fed by the Blunder Creek catchment, which originates from the nearby rainforest-covered escarpment to the east of the swamp and probably responsible for the long-distance transport of rainforest pollen to the site during flood events. A key consequence of these results is that there have been no significant climatic alterations (e.g. significantly wetter phases) that have facilitated the further expansion westward of rainforest. That is, once fully established between 9500 and 7500 cal BP (Haberle 2005), the rainforest-sclerophyll boundary was highly stable, with only minor fluctuations at the fringe of this boundary. These alterations at the fringe could be associated with slightly wetter and drier phases linked to ENSO variability, particularly during the late Holocene, as well as human use of fire influencing the boundary over the length of the Holocene period (Ash 1988).

Although it does not reveal a significant expansion of rainforest during the Holocene period, the Witherspoon Swamp records do suggest some significant climatic alterations (generally associated with precipitation changes) that reflect broader regional Holocene patterns. The WS 2 core suggests a drier environment around $8000 \mathrm{cal} \mathrm{BP}$, possibly indicating that mesophyll rainforest did not reach its modern-day distribution until ca. $7500 \mathrm{cal} \mathrm{BP}$, as suggested by the 
Lake Euramoo record (Haberle 2005). In fact, a wetter phase, characterised by an increase in sedges and sclerophyll arboreal taxa and a decline in grass, is seen in the WS 2 record from 180 $\mathrm{cm}$ to $140 \mathrm{~cm}$. This suggests higher precipitation during this early to mid-Holocene period, which is further supported by relatively high rainforest values in the WS 1 core at the base of this record (ca. $5000 \mathrm{cal} \mathrm{BP}$ ). In addition, a general drying trend is observed in the WS 1 record with the decline and virtual disappearance of Selaginella, as well as lower representation of Nymphoides at $100 \mathrm{~cm}$, probably reflecting a shift to lower water levels in the swamp. These results are similar to findings by Shulmeister and Lees (1995) from Groote Eylandt, Northern Territory, and by Luly et al. (2006) for the eastern shores of Cape York, Queensland, which suggests that these drying and wetting trends are a general feature of the sclerophyll forests and woodlands of northern Australia.

Some climatic variability is suggested by periodic increases in grass representation and charcoal values, alternating with increased values of rainforest taxa and sclerophyll arboreal taxa in both records. This vegetation alteration may be linked to the onset of ENSO conditions in the region ca. 5000 cal BP (i.e. a combination of E1 Niño and La Niña events) (Haberle and David 2004; Shulmeister and Lees 1995; Donders et al. 2007). A key change in the record appears to occur sometime after ca. $2000 \mathrm{cal} \mathrm{BP} \mathrm{(ca.} 60 \mathrm{~cm}$ to $40 \mathrm{~cm}$ in both WS 1 and WS 2), with a return to generally drier conditions, seen through the expansion of grass values at the expense of the sclerophyll arboreal taxa. There is an increase in ash content variability (values ranging from $30 \%$ to $70 \%$ ) from $60 \mathrm{~cm}$ in the WS 2 record, and this may reflect increased climatic variability beginning around $2000 \mathrm{cal} \mathrm{BP}$. These alterations in ash content may represent changes in fluvial inputs of lithogenic sediments from the surrounding areas, with higher rainfall increasing inorganic content, and lower precipitation increasing organic values through less mineral matter transported to the swamp. Finally, a return to wetter conditions, lower grass values and higher sclerophyll arboreal representation is observed at the top of both records ( $0 \mathrm{~cm}$ in WS1 and $20 \mathrm{~cm}$ in WS 2), although this may also be associated with European disturbance. Generally, these alterations are consistent with similar changes in the Lake Euramoo record (Haberle 2005), which suggest that climatic variability associated with ENSO activity affected rainforests, sclerophyll forests and woodlands in a comparable fashion.

\section{Implications for human occupation of the sclerophyll communities of the Wet Iropics region}

The Witherspoon Swamp record has a number of implications for understanding potential human impacts on the sclerophyll communities of the Wet Tropics region of northern Australia. The presence of extensive swamp deposits extending back to at least the past 8000 years from Witherspoon Swamp suggests that this site may have formed a good camping area, with a source of permanent water and extensive food resources located within and around the swamp. To date, no archaeological surveys have been conducted around Witherspoon Swamp and further research should be undertaken to investigate whether this site did form an important resource for Aboriginal communities during the Holocene period. However, the pollen and charcoal record does not provide any clear evidence of Aboriginal impacts on the surrounding landscape through anthropogenic burning. Nearby records from the rainforest communities, including Lake Euramoo (Haberle 2005) and Lynch's Crater (Hiscock and Kershaw 1992), suggest - through increased burning, expansion of disturbance indicators (i.e. Macarangal Mallotus) and destruction of swamp forest at Lynch's Crater - that greater occupation of the region occurred over the past 5000 years. There are slight peaks in charcoal in the Witherspoon Swamp records at ca. $2000 \mathrm{cal}$ BP that may reflect increased human impacts, but as suggested 
by Haberle and David (2004), it is extremely difficult to disentangle the relative roles of human impact and climate in landscape change for the humid tropics region.

Increased climatic variability through increased ENSO intensity and frequency around 2000 years ago may have facilitated a significant change in Aboriginal subsistence strategies. Gagan et al. (2004) suggest that the most intense period of ENSO activity occurred from 2500 to 1700 years ago, with a reduction in rainfall in the order of $20 \%$ to $40 \%$, as well as precipitation becoming highly seasonal. Cosgrove et al. (2007) suggest that this significant climatic event made the surrounding sclerophyll woodlands and forests more marginal for human subsistence and facilitated the development of the Aboriginal rainforest culture based on toxic nut cultivation and processing. As discussed previously, the WS 2 record observes an increase in ash content variability from ca. 2000 years ago and this may reflect increased climatic variability associated with increased ENSO activity. In addition, the WS 1 record indicated an increase in rainforest and sclerophyll arboreal taxa around $50 \mathrm{~cm}$ to $45 \mathrm{~cm}$, which then declines significantly at $40 \mathrm{~cm}$, associated with a corresponding increase in grass. This decline has been directly dated to around 2000 years and also suggest highly variable climates associated with increased ENSO activity. These results support Cosgrove et al.'s (2007) suggestions that alterations in ENSO activity may be a key driver of subsistence changes for the Aboriginal people of the Wet Tropics region. However, further research is required to verify these results in terms of high-resolution palynological analysis of the Witherspoon Swamp record and examination of other sites within the sclerophyll communities of the region, as well as direct evidence, through artefacts, of human occupation changes around the margin of the swamp. Finally, both the WS 1 and WS 2 records provide evidence of European occupation (Zones WS $1 \mathrm{~F}$ and WS 2F), with an increase in Asteraceae (Tublifloreae) pollen, decreased representation of grass, increased sclerophyll arboreal taxa values and decreased burning. These alterations most likely reflect activities associated with cattle grazing, particularly the imposition of fire suppression, and support similar findings in the Lake Euramoo record (Haberle 2005).

\section{Conclusion}

Landscape changes observed within both the sclerophyll and rainforest communities of the Wet Tropics region of northern Australia during the Holocene period suggest a significant amount of environmental variability. Key alterations include: a dry early Holocene; an early to mid-Holocene climatic optimum phase; and onset of drier, more variable environments, with greatest variability occurring around 2500 to $1700 \mathrm{cal} \mathrm{BP}$, most likely associated with enhanced ENSO activity from the mid-Holocene (from 5000 years ago onwards). These natural climatic alterations may have had a profound impact on human activity within the region, and as suggested by Cosgrove et al. (2007), this increased climatic variability from 2500 to $1700 \mathrm{cal}$ $\mathrm{BP}$ may have played a key role in the development of the unique indigenous rainforest culture of the region. However, the Witherspoon Swamp record, along with other sites from the modern rainforest communities of the region (particularly Lake Euramoo, Haberle 2005), also suggest that once established, the rainforest-sclerophyll boundary was highly stable during the Holocene period and that landscape alterations occurred within each community, rather than resulting in a significant expansion/contraction of these communities. These results also suggest that complex interactions between natural climate change and human impacts played a key role in shaping the northern Australian Wet Tropics environment during the Holocene period.

\section{Acknowledgements}

We thank Mr Trevor Austin, of Blunder Park, for permission to core Witherspoon Swamp 
and the Jirrbal people for their support and permission to work in their traditional country. Radiocarbon dating of the WS 2 samples was supported by AINSE Grant AINGRA08049. Research funding for this project was provided by a research grant from the School of Geography, Planning and Environmental Management, the University of Queensland and by an Australian Research Council Discovery Project grant (DP0986579). The authors would like to thank two anonymous reviewers for constructive comments on the manuscript.

\section{References}

Ash, J. 1988. The location and stability of rainforest boundaries in north-eastern Queensland, Australia. Journal of Biogeography 15:619-630.

Chen, Y. 1988. Early Holocene population expansion of some rainforest trees at Lake Barrine basin, Queensland. Australian Journal of Ecology 13:225-233.

Cosgrove, R., Field, J. and Ferrier, Å 2007. The archaeology of Australia's tropical rainforests. Palaeogeography, Palaeoclimatology, Palaeoecology 251:150-173.

Crowley, G.M. and Gagan, M.K. 1995. Holocene evolution of coastal wetlands in wet-tropical northeastern Australia. Holocene 5:385-399.

Crowley, G.M., Anderson, P., Kershaw, A.P. and Grindrod, J. 1990. Palynology of a Holocene marine transgressive sequence, lower Mulgrave River valley, north-east Queensland. Australian Journal of Ecology 15:231-40.

Donders, T.H., Haberle, S.G., Hope, G., Wagner, F. and Visscher, H. 2007. Pollen evidence for the transition of the Eastern Australian climate system from the post-glacial to the present-day ENSO mode. Quaternary Science Reviews 26:1621-1637.

Gagan, M.K., Johnson, D.P., and Crowley, G.M. 1994. Sea level control of stacked late Quaternary coastal sequences, central Great Barrier Reef. Sedimentology 41:329-351.

Gagan, M.K., Hendy, E.J., Haberle, S.G. and Hantoro, W.S. 2004. Post-glacial evolution of the Indo-Pacific Warm Pool and E1 Niño-southern Oscillation. Quaternary International 118-119:127-143.

Grimm, E.C. 1987 CONISS: a FORTRAN 77 program for stratigraphically constrained cluster analysis by the method of incremental sum of squares. Computers and Geoscience 13:13-35.

Grimm, E.C. 2004. TGView Version 2.0.2, Springfield, IL, USA: Illinois State Museum.

Grindrod, J. 1985. The palynology on a prograded shore, Princess-Charlotte Bay, North Queensland, Australia. Journal of Biogeography 12:323-348.

Grindrod,J. and Rhodes, E.G.1984. Holocene sea-level history of a tropical estuary: Missionary Bay, north Queensland. In: Thom, B.G. (ed), Coastal Geomorphology in Australia, pp. 151177. Sydney: Academic Press.

Haberle, S.G. 2005. A 23,000-yr pollen record from Lake Euramoo, Wet Tropics of NE Queensland, Australia. Quaternary Research 64:343-356.

Haberle, S.G. and David, B. 2004. Climates of change: human dimensions of Holocene environmental change in low latitudes of the PEPII transect. Quaternary International 118-119:165-179.

Hiscock, P. and Kershaw, A.P. 1992. Palaeoenvironments and prehistory of Australia's Top End. In: Dodson, J. (ed), The Naive Lands: Prehistory and Environmental Change in Australia and the Southwest Pacific, pp. 43-71. Melbourne: Longman Cheshire.

Hughen, K., Southon, J., Lehman, S., Bertrand, C. and Turnbull, J. 2006. Marine-derived 14C calibration and activity record for the past 50,000 years updated from the Cariaco Basin. Quaternary Science Reviews 25:3216-3227.

Kershaw, A.P. 1970. A pollen diagram from Lake Euramoo, North-East Queensland, Australia. 
Nerw Phytologist 69:785-805.

Kershaw, A.P. 1971. A pollen record from Quincan Crater, north-east Queensland, Australia. New Phytologist 70:669-805.

Kershaw, A.P. 1975. Stratigraphy and pollen analysis of Bromfield Swamp, north-eastern Australia. New Phytologist 75:173.

Kershaw, A.P.1983. A Holocene pollen record from Lynch's Crater, north-eastern Queensland, Australia. New Phytologist 94:399-412.

Kershaw, A.P. 1986. The last two glacial-interglacial cycle from northeastern Australia: implication for climate change and Aboriginal burning. Nature 322:47-49.

Kershaw, A.P. 1994. Pleistocene vegetation of the humid tropics of northeastern Queensland, Australia. Palaeogeography, Palaeoclimatology, Palaeoecology 109: 399-412.

Kershaw, A.P., van der Kaars, S. and Moss, P.T. 2003a. Late Quaternary Milankovitch-scale climate change and variability and its impact on monsoonal Australia. Marine Geology 201:81-95.

Kershaw, A.P., Moss, P.T. and van der Kaars, S. 2003b. Causes and consequences of long-term climatic variability on the Australian continent. Freshwater Biology 48:1274-1283.

Kershaw, A.P., Bretherton, S.C. and van der Kaars, S. 2007. A complete pollen record of the last 230 ka from Lynch's Crater, north-eastern Australia Palaeogeography, Palaeoclimatology, Palaeoecology 251:23-45.

Luly,J.G., Grindrod,J. and Penny, D. 2006. Holocene palaeoenvironments and change at ThreeQuarter Mile Lake, Silver Plains Station, Cape York Peninsula, Australia. The Holocene 16:1085-1094.

Moss, P.T. and Kershaw, A.P. 2000. The last glacial cycle from the humid tropics of northeastern Australia: comparison of a terrestrial and a marine record. Palaeogeography, Palaeoclimatology, Palaeoecology 155:155-176.

Moss, P.T. and Kershaw, A.P. 2007. A late Quaternary marine palynological record (oxygen isotope stages 1 to 7) for the humid tropics of northeastern Australia based on ODP site 820. Palaeogeography, Palaeoclimatology, Palaeoecology 251:4-22.

Nichols, N. 1992. Historical El Niño/Southern Oscillation variability in the Australasian region. In: Diaz, H.F. and Markgraf, V. (eds), El Niño: Historical and Paleoclimatic Aspects of the Southern Oscillation, pp. 167-179. Cambridge: Cambridge University Press.

Shulmeister, J. and Lees , B.G.1995. Pollen evidence from tropical Australia for the onset of an ENSO-dominated climate at c. 4000 BP. The Holocene 5:10-18.

Tracey, J.G. 1982. The vegetation of the humid tropical region of north Queensland. Melbourne: CSIRO.

van der Kaars, W.A. 1991. Palynology of eastern Indonesian marine piston-cores: A late Quaternary vegetational and climatic record for Australasia. Palaeogeography, Palaeoclimatology, Palaeoecology 85:239-302.

Walker, D. 2007. Holocene sediments of Lake Barrine, north-east Australia, and their implications for the history of the lake and catchment environments. Palaeogeography, Palaeoclimatology, Palaeoecology 251:57-82.

Walker, D and Chen, Y. 1987. Palynological light on tropical rainforest dynamics. Quaternary Science Revierws 6:77-92.

Wang, X., van der Kaars, S., Kershaw, P., Bird, M. and Jansen, F.1999. A record of fire, vegetation and climate through the last three glacial cycles from Lombok Ridge core G6-4, eastern Indian Ocean, Indonesia. Palaeogeography, Palaeoclimatology, Palaeoecology 147:241-256. 